\title{
Harmonising the fields of invasion science and forest pathology
}

\author{
Trudy Paap', Michael J. Wingfield', Treena I. Burgess ${ }^{1,2}$, \\ Joseph M. Hulbert ${ }^{3,4}$, Alberto Santini ${ }^{5}$
}

I Department of Biochemistry, Genetics and Microbiology; Forestry and Agricultural Biotechnology Institute (FABI), University of Pretoria, Pretoria, 0002, South Africa 2 Centre for Climate Impacted Terrestrial Ecosystems, Harry Butler Institute, Murdoch University, Murdoch, 6150, Australia 3 Department of Plant and Soil Science; Forestry and Agricultural Biotechnology Institute (FABI), University of Pretoria, Pretoria, 0002, South Africa 4 Department of Plant Pathology, Washington State University Research \& Extension Centre, Puyallup 98371, USA 5 Institute for Sustainable Plant Protection, National Research Council, Sesto Fiorentino, 50019, Italy

Corresponding author: Trudy Paap (trudy.paap@fabi.up.ac.za)

Academic editor: D. M. Richardson | Received 7 April 2020 | Accepted 25 August 2020 | Published 15 October 2020

Citation: Paap T, Wingfield MJ, Burgess TI, Hulbert JM, Santini A (2020) Harmonising the fields of invasion science and forest pathology. In: Wilson JR, Bacher S, Daehler CC, Groom QJ, Kumschick S, Lockwood JL, Robinson TB, Zengeya TA, Richardson DM (Eds) Frameworks used in Invasion Science. NeoBiota 62: 301-332. https://doi.org/10.3897/ neobiota.62.52991

\begin{abstract}
Invasive alien species are widely recognised as significant drivers of global environmental change, with far reaching ecological and socio-economic impacts. The trend of continuous increases in first records, with no apparent sign of saturation, is consistent across all taxonomic groups. However, taxonomic biases exist in the extent to which invasion processes have been studied. Invasive forest pathogens have caused, and they continue to result in dramatic damage to natural forests and woody ecosystems, yet their impacts are substantially underrepresented in the invasion science literature. Conversely, most studies of forest pathogens have been undertaken in the absence of a connection to the frameworks developed and used to study biological invasions. We believe this is, in part, a consequence of the mechanistic approach of the discipline of forest pathology; one that has been inherited from the broader discipline of plant pathology. Rather than investigating the origins of, and the processes driving the arrival of invasive microorganisms,
\end{abstract}

Copyright Trudy Paap et al. This is an open access article distributed under the terms of the Creative Commons Attribution License (CC BY 4.0), which permits unrestricted use, distribution, and reproduction in any medium, provided the original author and source are credited. 
the focus of pathologists is generally to investigate specific interactions between hosts and pathogens, with an emphasis on controlling the resulting disease problems. In contrast, central to the field of invasion science, which finds its roots in ecology, is the development and testing of general concepts and frameworks. The lack of knowledge of microbial biodiversity and ecology, speciation and geographic origin present challenges in understanding invasive forest pathogens under existing frameworks, and there is a need to address this shortfall. Advances in molecular technologies such as gene and genome sequencing and metagenomics studies have increased the "visibility" of microorganisms. We consider whether these technologies are being adequately applied to address the gaps between forest pathology and invasion science. We also interrogate the extent to which the two fields stand to gain by becoming more closely linked.

\section{Keywords}

coevolution, emerging, forest pathogens, invasion framework, invasive forest pathogens, microbial invasions, tree disease

\section{Introduction}

Invasive alien species (IAS) present a major threat to global biodiversity, ecosystem services, economies and human health. In the present era of globalisation, and with no end in sight to the accumulation of alien species worldwide (Seebens et al. 2017), this threat continues to grow (Pyšek et al. 2020). The field of invasion science has been established to address the issues arising from the introduction of alien species and resulting biological invasions. It is grounded in invasion ecology, but has expanded to include non-biological lines of enquiry, including economics, ethics, sociology, and inter- and transdisciplinary studies (Hui and Richardson 2017). While IAS are represented by organisms across all taxonomic groups, much of the body of work in the field of invasion science has been focussed on plants and animals (Pyšek et al 2008; Wilson et al. 2020a). Many key texts fail to consider microorganisms, or if they are mentioned, they do so only briefly (e.g. Mooney et al. 2005; Lockwood et al. 2013). In contrast, there have been a number of recent reviews on microbial invasions, including invasive forest pathogens (IFPs), however, these have generally been written by microbiologists, or where dealing specifically with forest pathogens, forest pathologists (Desprez-Loustau et al. 2007; Fisher et al. 2012; Santini et al. 2013; Gladieux et al. 2015; Ghelardini et al. 2017). Nonetheless, IFPs remain generally poorly connected with invasion frameworks, limiting the application and usefulness of these concepts.

The low level of recognition regarding the importance of forest pathogens in invasion science is concerning, when considering the substantial effects of IFPs and their ability to completely alter landscapes. IFPs have been responsible for many disastrous outbreaks of diseases in commercial, natural and urban forests. Well known historical examples include chestnut blight (caused by Cryphonectria parasitica), Dutch elm disease (Ophiostoma ulmi sensu lato), Phytophthora cinnamomi in southwest Australia, and in more recent history, sudden oak death (Phytophthora ramorum) and ash dieback (Hymenoschyphus fraxineus) (e.g. Brasier and Buck 2001; Rizzo and Garbelotto 2003; 
Shearer et al. 2007; Pautasso et al. 2013; Rigling and Prospero 2018). These and other diseases have fundamentally altered ecosystems, with entire tree species practically eliminated from the landscape. For example, the second pandemic of Dutch elm disease is estimated to have killed between 30 and 50 million elms in the United Kingdom alone (Brasier 2008). Likewise, chestnut blight functionally removed mature American chestnut (Castanea dentata) trees from natural landscapes within 30 years of its arrival (Brasier, 2008; Loo, 2008), and sudden oak death is having a similar impact on tanoak (Notholithocarpus densiflorus) in Oregon and California (Cobb et al. 2012). Common ash (Fraxinus excelsior) is now threatened in much of its natural distribution across Europe, with mortality rates as high as $85 \%$ recorded from sites infected with H. fraxineus (Pautasso et al. 2013; Coker et al. 2019). In addition to dramatic changes in forest canopy composition, direct and indirect effects on communities, including losses of important ecosystem services, are increasingly reported following these invasions. Mitchell et al. (2014) highlighted the wide-ranging ecological implications of ash dieback resulting from $H$. fraxineus infection. Likewise, the invasive fungal pathogen Austropuccinia psidii (cause of myrtle rust), has significantly altered species richness and abundance in Australian rainforest communities, within a short period of time (Fernandez-Winzer et al. 2020).

Coevolution between forest pathogens and their hosts, together with pressures from competition, predation and parasitism, has contributed to the complexity and stability of natural ecosystems. Severe disease outbreaks by native pathogens under natural environmental conditions, are therefore rare (Burdon and Thrall 2009). Importantly, this coevolution between hosts and pathogens has occurred under a particular set of environmental conditions (Stenlid and Oliva 2016). Pathogens are therefore contained by geographical, environmental and evolutionary barriers, with these barriers impeding spread to novel hosts and limiting their potential to cause severe disease outbreaks. However, release from any one of these barriers may result in pathogenic behaviour, and the emergence of a new disease.

The term emerging infectious disease (EID) has its history in the medical and veterinary fields, but has also been applied to diseases of plants (Anderson et al. 2004). Of the three means by which an EID can arise, generally only one, the crossing of geographical barriers due to human mediated dispersal, is recognised as a process leading to biological invasions (Ogden et al. 2019). Within the context of forest pathology, a challenge when faced with the emergence of a new disease is determining whether this is due to the introduction of an alien species, or the consequence of a native pathogen being favoured by changing environmental conditions. The latter scenario has become increasingly common under conditions of habitat disturbance and climate change (Desprez-Loustau et al. 2006; Paap et al. 2018). The lack in knowledge of microbial biodiversity and ecology, speciation and geographic origin confound the problem of defining emerging diseases from an invasion perspective. While recent advances in molecular technologies have increased the "visibility" of microorganisms, the paucity of information remains a challenge. It is, therefore, understandable, but remains concerning, that pathogens are strikingly underrepresented in invasion science. 
The clearest evidence for this underrepresentation is that among the IUCN list of 100 of the World's Worst Invasive Alien Species (Lowe et al. 2000), only six are microorganisms. And of these, only three (Cryphonectria parasitica, Ophiostoma ulmi sensu lato and Phytophthora cinnamomi) are forest pathogens. A more recent example is that of the European Union list of alien species of Union Concern. Despite two updates, forest pathogens (and microorganisms in general) remain absent from this list (European Union 2019). Another example is South Africa's http://invasives.org. za, which includes information about invasive plants, animals and insects, but not microorganisms, despite the presence of globally regulated species such as Austropuccinia psidii and Fusarium circinatum (Wingfield et al. 2008; Roux et al. 2013).

There have been previous calls for increased cooperation between microbiologists and invasion scientists. For example, Desprez-Loustau et al. (2007) highlighted the underrepresentation of fungi in the field of biological invasions, most likely due to a lack of scientific knowledge of fungal biodiversity and ecology. They hoped to raise awareness among mycologists and ecologists of the fungal dimension of invasions, and they identified the need to intensify research in fungal ecology to address the issue of future introductions. More recently, Wingfield et al. (2017) observed that forest pathologists have frequently undertaken epidemiological studies in the absence of any reference to, or reflection on, invasion science principles or frameworks, and called for closer collaboration between the disciplines.

This review interrogates the history of the disciplines of forest pathology and invasion science, seeking insights as to why the two fields have remained relatively unconnected. We consider several explanations for this disconnect and highlight the need to resolve these issues. By adopting the frameworks of invasion science, forest pathologists may be able to better understand how and why invasions occur. Importantly, also where, when and how invasions can be stopped or mitigated. The issue of microbial invasions has been described as one of the most pressing topics facing invasion science (Ricciardi et al. 2017; Thakur et al. 2019). Therefore, a greater inclusion of IFPs and microorganisms in general, is essential for the continued advancement of the field of invasion science. For the purpose of this review we consider IFPs in the strict sense, as a subgroup of IAS i.e. of alien origin and a consequence of human mediated dispersal.

\section{A brief history of forest pathology and invasion science}

\section{Forest pathology}

The Greek philosopher Theophrastus (c. 371 - c. 287 BC) was the first to study and write about disease of trees, cereals and legumes. However, it was not until the mid1800 s that the role of pathogenic microorganisms in causing plant disease was understood. Anton de Barry, a German surgeon, botanist and microbiologist, is recognised as the founding father of modern plant pathology and modern mycology. In 1861, de 
Barry documented in detail the life cycle of Phytophthora infestans and provided experimental evidence to demonstrate its role of as the causal agent of potato late blight. In doing so, he refuted the long-standing doctrine of "spontaneous generation", and the discipline of physiological plant pathology was born (Kutschera and Hossfeld 2012).

Forest pathology emerged soon afterwards, as a branch of plant pathology dealing with diseases of woody plants growing in natural ecosystems, plantations and urban environments. The German forester Robert Hartig is widely regarded as the "father" of forest pathology. His work characterised and linked Heterobasidion annosum to conifer root and butt rot (published in 1874), refuting the notion of decay being responsible for the spontaneous generation of fungi by showing that fungi were the cause of decay (Shigo 1967).

The first half of the 1900s saw only a small number of forest pathologists working worldwide. Interestingly much of today's understanding of forest pathology is still underpinned by the work of these few early pioneers (Boyce 1938; Peace 1962). Historically, the focus of forest pathology was centred on determining the cause and control of specific disease problems; essentially, a mechanistic approach adopted from the broader field of plant pathology. Rather than investigating the origins of the microorganism, the processes driving its arrival, or determining the basic underlying biology of the disease system, the emphasis was primarily on controlling the resulting disease problem.

Forest pathology has been strongly shaped by the influences of microbiology and health sciences, quintessential to its plant pathology roots. However, forest pathology is also a sub-field of forestry and as such, has dealt with long time scales and diverse environments, much more so than classic agronomic crop-based plant pathology (Desprez-Loustau et al. 2016). In addition to severe disease outbreaks caused by IFPs, forest health is also marked by important tree declines. Manion (1981) formalised the tree decline concept, incorporating abiotic and biotic predisposing, inciting and contributing factors. In contrast to crop pathology, where systems are simplified and intensely managed, forest pathology deals with complex and long-lived ecosystems. The environmental differences play a significant role in determining host-pathogen interactions and their subsequent outcomes.

Within the context of forest pathology, two diverging branches of the discipline have arisen. This has come about as a result of two broad settings in which forestry is undertaken; plantation forestry versus natural and semi-natural forests. Planted forests are generally very simplified ecosystems, more similar to a crop than to a natural forest. This type of silviculture, combined with a wide use of non-native tree species is the dominant, if not exclusive, form of forestry in the Southern Hemisphere (South America, South Africa, New Zealand and to an extent, Australia), and also East and South East Asia. They are typically monospecific, and characterised by both native and non-native trees mostly of the genera Pinus, Eucalyptus and Acacia (Wingfield et al. 2015; Burgess and Wingfield 2017). Consequently, the focus of forest pathology today has arguably remained more closely linked to the mechanistic approach of plant pathology. While there is some plantation forestry in the Northern Hemisphere 
including genera of Pinus, Picea, Pseudotsuga, Populus and Eucalyptus, the experiences of forest pathologists in the Northern Hemisphere have tended to come mostly from a silviculture based on native species cultivated in natural or semi-natural environments, or from plantations of native species. Here, silvicultural practices have long been implemented to manage native forest tree species with the objective of optimising timber production and maintaining tree cover. A less mechanistic and more ecological approach to forest pathology has evolved from this setting. Broadly speaking, management of native forest tree species, including dealing with disease problems, has long been practiced in Europe, North America and Russia (Manion et al. 1981; Tainter and Baker 1996). However, until recently, response to the emergence of a new forest disease has focused on how to manage the outbreak, and not on why, how and from where the causal agent has arrived. This approach is typically mechanistic and is likely derived not only from plant pathology, but also from the past approach to human diseases, where treatments have historically focused on limiting symptoms, as opposed to eliminating the causal agent.

\section{Invasion science}

The discipline of invasion science is a relatively young field. In 1958, the British biologist Charles Elton (1958) published The Ecology of Invasions by Plants and Animals, describing for the first time the biology of invasive organisms, and noting their importance as drivers of ecosystem change. By the 1980s, there was a growing body of accounts in the literature of non-native species invading novel environments. There was also the realisation that increased world trade and travel were leading to an increased frequency of biological invasions. Furthermore, that the negative effects associated with the invasion of non-native species presented one of the greatest threats to native ecosystems and biodiversity (Macdonald et al. 1986; Mooney and Drake 1986).

A meeting of the Scientific Committee on Problems of the Environment (SCOPE) held in 1982, identified that the invasive spread of organisms introduced by humans outside of their native ranges was a problem of global concern (Reichard and White 2003). In the period following this meeting, an important series of books and journal articles were produced on the topic. And it was largely from this foundation that the field of invasion science emerged as a discipline in its own right (Hui and Richardson 2017).

An important issue encountered in the field of invasion science is that researchers concerned with different taxa and different environments developed their science and the associated terminology, along parallel but independent lines. This has led to the use of synonymous terms for the same processes, and multiple definitions for the same term. There are also differences in how the process of invasion is described with regard to the taxon being studied. Consequently, different frameworks have been adopted across the different taxa and environments (Blackburn et al. 2011). This is probably most obvious in the approaches used in the study of plant and animal invasions. Plant biologists have commonly adopted the terminologies and frameworks of Richardson et al. (2000), 
while researchers undertaking studies of animal invasions have generally adopted the frameworks (or modifications thereof) first proposed by Williamson (1996).

The lack of agreement on usage of terminology has been acknowledged as bringing an added complication to an already challenging field (Blackburn et al. 2011; Lockwood et al. 2013; Pereyra 2016; Courchamp et al. 2017). In the last decade, there has been a strong push to align the terminologies and concepts used across different taxa and environments such as the terminology proposed by the IUCN Environmental Impact Classification for Alien Taxa (EICAT) (Hawkins et al. 2015). Perhaps a redeeming factor here has been that these scientists, whether dealing with plant invasions or animal invasions, come from fields that are strongly based in ecology and conservation biology. This has resulted in a strong common approach with regards to addressing the problem. It has clearly also assisted greatly in moving towards a common framework for studying plant and animal invasions, which has been achieved through the development of a "unified framework for biological invasions", developed by Blackburn et al. (2011). A similar effort to better align terminologies between the fields of invasion science and forest pathology has yet to be undertaken. Box 1 includes a number of terms for which varying definitions are applied by the two fields.

\section{Recognition of invasion science by forest pathologists}

The term "invasion" was first linked with a forest pathogen by Weste and Taylor (1971), to describe the development of disease following the establishment and spread of Phytophthora cinnamomi in the Brisbane Ranges of Australia. It was not until the early 2000s, however, that "invasive" and variations thereof, were more widely applied to forest pathogens, e.g. Phytophthora lateralis Port Orford Cedar root rot (Jules et al. 2002), Phytophthora kernoviae (Brasier et al. 2005). The continued introduction of economically and environmentally damaging forest pathogens and their establishment in novel areas has highlighted the need for forest pathologists to look to invasion science for insights on how to better understand the processes leading to invasion and spread of IFPs (Brasier 2008; Loo 2008; Santini et al. 2013; Scott et al. 2019).

A rising interest and acknowledgment of the importance of invasion science as a concept relevant to forest pathology is reflected in the uptake of the use of the term "invasive", or variations thereof, in contemporary publications by forest pathologists. To provide a view of how this has changed in recent years, we conducted a search using the Web of Science BIOSIS Citation Index ${ }^{\mathrm{SM}}$ record data, for articles published between 1965 and 2019 that included the terms "forest", "pathogen" and "invas*". For comparison, we conducted searches for the same period using the terms "emerg*", "alien", "exotic" and "non-native", together with "forest" and "pathogen". The results are shown in Figure 1. Throughout the 1990s and early 2000s, there are few records for any combination of the terms. From this point, however, there is a marked increase in the use of the terms "invas*" and "emerg*", with steady increases also for "alien", "exotic" and "non-native". There is a continued increase in records including the terms 
Box I. Terminology used in this review.

Alien/non-native/non-indigenous/exotic/foreign - An organism (species, subspecies or lower taxon) transported outside of its native range, either intentionally or unintentionally by human agency.

Native/indigenous - An organism that has evolved in a given area or that arrived there by natural means, without human intervention.

Endemic - An organism occurring naturally only in a particular geographic region. In a pathology context, endemic may also refer to a pathogen (or resulting disease) that is characteristic of a particular population, environment or region (i.e. it is permanently established).

Cryptogenic - Taxa deemed to be alien, but without definitive supporting evidence.

Invasibility - The properties of a community, habitat or ecosystem determining its inherent vulnerability to invasion by alien organisms.

Invasiveness - The traits of an organism e.g. life-history traits and modes of reproduction, that determine its ability to invade, i.e. to overcome the barriers to invasion.

Invasion process - A series of stages (transport, introduction, establishment, and spread) through which an organism must pass before it is considered invasive.

Invasive alien species (IAS) - A self-sustaining (naturalised/established) population of a species accidentally or intentionally introduced by human actions, to an area outside of their native geographic range, into an area where they are not naturally present. While not all definitions include impact, others specify IAS cause, or are likely to cause, socio-cultural, economic, or environmental harm or harm to human health.

Emerging alien species - An organism whose incidence or geographical distribution is increasing notably, or a newly introduced or newly described species. The causes of emergence may be multiple and complex, but it is generally accepted that human activities (e.g. accidental introduction, modifications of land use) play an important role (Seebens et al. 2018).

Emerging Infectious Disease - An infectious disease appearing in a population for the first time, or that may have existed previously but is rapidly increasing in incidence or geographic range (WHO: https://apps.who.int/iris/ handle/10665/204722; Ogden et al 2019).

Invasive forest pathogen (IFP) - A pathogenic microorganism (a species, subspecies, race, or forma specialis) introduced by human actions to an area outside its natural distribution, where it behaves as an agent of disease on native or alien trees or shrubs.

Epidemiology - The study of the spatial and temporal changes occurring during epidemics caused by populations of pathogens in populations of hosts, under influences of the environment - in short, how disease develops in populations.

Naturalised - A self-sustaining population of an intentionally or unintentionally introduced alien species that has adapted to, and reproduces successfully, in its new environment. The term established has been used synonymously.

Spill-over - A concept first proposed for animal pathogens, to describe the process of pathogen transmission from a reservoir population with a high pathogen prevalence, to a novel host population with which it has come into contact (Daszak et al. 2000). The concept has also been defined as "cross-species transmission of disease without the establishment of a self-sustainable population onto the new host” (Giraud et al. 2010).

Spill-back - If an alien species is a competent host for a native pathogen/parasite, the population of the pathogen/ parasite builds up on this host and "spills-back" onto native hosts (Daszak et al. 2000).

Host-jump - From an evolutionary perspective, it is defined as "a colonisation of a new host species that leads to increasing genetic separation from the parent population until speciation is complete" (Thines 2019). In an ecological sense, refers to a pathogen moving from its coevolved host to a novel host, a situation facilitated by contact between previously geographically separated host species (e.g. host-jump from introduced host to native host in novel environment, or native microorganism jumping to introduced host). Also referred to as "host-shift".

Hitchhikers - Within a forest pathology context, the term refers to microorganisms transported with asymptomatic plants, including pathogens. While "hitchhiker" has not been formally defined in the invasion literature, it has been used to describe species that are carried by chance or unknowingly, in relation to the "stowaway" pathway (Harrower et al. 2018). This pathway, however, precludes biological connection to the organism with which they are transported. The definition by forest pathologists would place it within the "contaminant" pathway of the Convention on Biological Diversity classification, however, there is no instance in the invasion terminology linking it to this pathway.

"invas*" and "emerg*", and while "exotic" tracks these for a number of years, use of the latter three terms stabilises in contrast to the continued rise of "invas*" and "emerg*". The results reflect the uptake of "invasive", or variations thereof, by forest pathologists, 


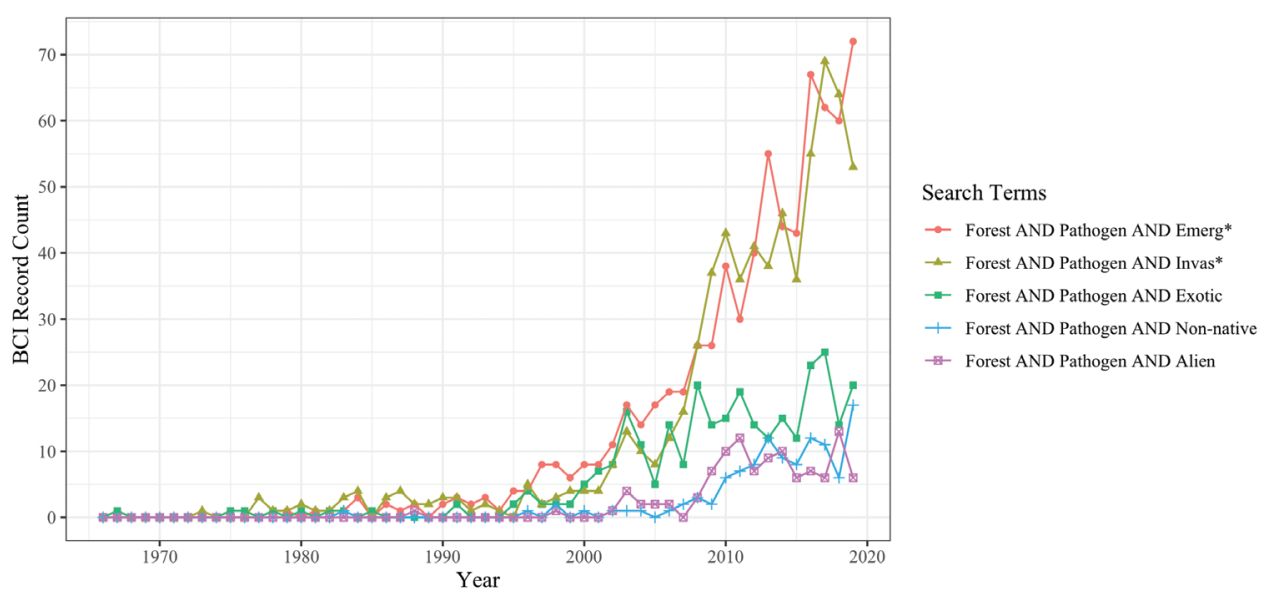

Figure I. Number of record counts returned from a Web of Science search including the terms "forest" and "pathogen" together with the terms "invas*", "emerg*", "alien", "exotic" and "non-native", for the years 1965-2019.

but also demonstrate that "emerging" remains a relevant concept. It is appropriate for describing diseases caused by cryptogenic species, and is also the most appropriate term to apply to the growing number of instances where native microorganisms become disease-causing agents under global change. Also, of note is that invasion scientists have recently started using the term "emerging" to acknowledge the challenge of invasions by organisms not previously encountered as aliens (Seebens et al. 2018). The term "emerging alien species" is used to describe those that are detected as aliens for the first time, i.e. with no previous invasion history (Seebens et al. 2018), consequently, it is challenging to predict their impact and spread (Pyšek et al. 2020).

\section{Policy and regulation}

Although pathologists have only recently adopted the invasion vocabulary, regulations regarding introduced plant pests and pathogens predate those on invasive species, with the first international convention to inhibit the spread of plant pests signed in 1878 (MacLeod et al. 2010). This highlights the early recognition of the threat posed by alien pests and pathogens, to the extent that it justified the establishment of international regulations. However, policy and regulation remain an area where plant and animal invaders are treated in different conventions to plant pests.

Phytosanitary regulations in most countries are based on the International Plant Protection Convention (IPPC; https://www.ippc.int/about/convention-text) and the World Trade Organisation (WTO) Agreement of the Application of Sanitary and Phytosanitary Measures (SPS, http://www.wto.org/english/res_e/booksp_el agrmntseries4_sps_e.pdf) (Eschen et al. 2015). The IPPC makes provision for international trade within a plant protection agreement, and aims to prevent and control 
the introduction and spread of pest organisms including weeds and invasive species, of plants, plant products, and wild plants, while the SPS provides for plant protection within a trade agreement (MacLeod et al. 2010). The current provisions have received criticism with regards to their ability to protect wildlife (including undomesticated plants), as the focus of the SPS and IPCC is largely on plants of economic importance (Dunn and Hatcher 2015; Roy et al. 2017). Further, a conflict of interest arises in that the primary aim of the WTO is to promote international trade rather than protect the environment, and the SPS aims to prevent countries from implementing protectionist trade barriers, to minimise the disruption plant health regulation might impose on trade (Brasier 2008; Dunn and Hatcher 2015).

The Convention on Biological Diversity (CBD) was established with the objectives of safeguarding biodiversity, ensuring its sustainable use, and equitable sharing of benefits from genetic resources. IAS are specifically addressed in the CBD Aichi Biodiversity Target 9: "By 2020, invasive alien species and pathways are identified and prioritised, priority species are controlled or eradicated, and measures are in place to manage pathways to prevent their introduction and establishment" (http://www. cbd.int/sp/targets/). While the IPPC and the CBD share some common ground and seek to find ways to cooperate (MacLeod et al. 2010), Roy et al. (2017) highlight the underrepresentation of pathogens in alien species regulation, and suggest the threats posed by alien pathogens (including IFPs) should receive greater attention by CBD Parties, to fully address the requirements of Aichi Target 9.

\section{Outdated paradigms}

There is a perception amongst some invasion scientists that forest pathology does not fit in studies of invasion biology because it is not related to the ecology of natural ecosystems. While this view may be somewhat appropriate for pathology conducted in agriculture or commercial forestry, not all forest pathology is conducted in this setting. There are also many situations where plantations are established adjacent to native forests accommodating related hosts, as is commonly found for Eucalyptus plantation forestry (Burgess and Wingfield 2017). Invasion scientists work within a paradigm focussed on native ecosystems, and while a large body of research on invasions applies to natural areas, not all IAS affect natural ecosystems, and urban areas are particularly vulnerable to the establishment of IASs (Cadotte et al. 2017; Paap et al. 2017a; Potgieter et al. 2020). In addition to aiding the introduction and establishment of IASs, urban areas may also act as bridge-heads from which invasive species may spread out of cities (Paap et al. 2017a; Reed et al. 2020; Potgieter and Cadotte 2020). It can be argued that until the 1980s, biological invasions by plants and animals were considered as confined to anthropogenically disturbed areas. One of the working groups of the SCOPE programme on ecology of biological invasions was specifically tasked to address invasions in nature reserves, asking 'Can an undisturbed community be invaded by introduced species?' (Usher 1988). It is only 
in more recent years that a shift has occurred towards studying invasions in natural environments (Foxcroft et al. 2017).

Many forest pathologists, even contemporary ones, have come from a classical plant pathology background, as opposed to one focussed on forestry or ecology. Consequently, their studies have had a stronger focus on local and micro-processes, on individual organisms and their interactions, and on finding immediate solutions to the problem, rather than embracing a more ecological approach (Wingfield et al. 2017). While many studies conducted into tree declines and tree diseases are based on the disease triangle or tree decline spiral, and are therefore less micro-process focused (Dukes et al. 2009; Ramsfield et al. 2016; Stenlid and Oliva 2016; Ghelardini et al. 2017), greater collaboration between invasion scientists and forest pathologists should be encouraged, especially in the Southern Hemisphere. Where such collaborations have been undertaken, greater insights into the dynamics of pathogen invasion have been identified (e.g. Soubeyrand et al. 2018).

\section{Emerging forest diseases vs invasive forest pathogens}

As previously noted, when investigating a new forest disease, it is not always immediately obvious whether the outbreak results from the arrival of an alien pathogen, or is driven by environmental change. The term "emerging" does not require knowledge of the alien status of the causal agent, and encompasses the range of scenarios under which diseases of trees can develop. This includes damaging host-jumps that may occur following the establishment of an alien host. A notable example is that of Austropuccinia psidii. This rust fungus jumped from native Myrtaceae in its natural range in South America to introduced Eucalyptus (Coutinho et al. 1998; Glen et al. 2007). Disease may also emerge where an environmental barrier is lifted e.g. habitat disturbance or climate change leading to a native microorganism causing disease on a coevolved native host (Paap et al. 2017b, 2018).

Where disease establishes as a result of the introduction of an alien pathogen, this may be on either a native or alien host, or both. In some instances, this constitutes "pathogen reunion", i.e. an alien pathogen arrives and establishes on a coevolved alien host, e.g. Teratosphaeria nubilosa, translocated with Eucalyptus trees, causing leaf blotch in plantation forests of South Africa (Hunter et al. 2008). Here, the novel environment together with monoculture plantings are conducive to disease development. An IFP may also establish on a naïve host which is alien to the invaded region e.g. Fusarium circinatum, causal agent of pine pitch canker, a devasting disease of plantation Pinus in South Africa (Wingfield et al. 2008). This fungus causes disease on Pinus spp. and with no congeners present in South Africa, has never jumped to native hosts. Lastly, there is the scenario of IFPs causing disease on native hosts, represented by some of the best-known forest diseases such as Dutch elm disease and chestnut blight. The challenge presented with regards to determining origins of disease-causing agents, as outlined in the above scenarios, has likely been a contributing factor to the historical underrepresentation of IFPs in invasion science. 


\section{Recognition of alien status}

Thousands of years of movement of plants, and with them the movement of microorganisms, has led to a situation where many pathogens are viewed as having cosmopolitan distributions i.e. naturalised (Santini et al. 2018). This is especially the case for agricultural crops. Historically, there has been less movement of forest trees than crop plants. But, with increasing international trade, especially the movement of plants for planting, and the growing use of planted forests, this situation is changing and resulting in increasing threats and challenges. However, the biogeography of most fungi (and microorganisms in general) remains largely unknown. The absence of such baseline data means that when a new disease emerges, it must be determined whether this is due to the arrival of an alien species, a host-jump by a native species to an alien planted host, or the result of a native pathogen that has evolved increased virulence or been favoured by changing environmental conditions. As such, assigning alien status is often challenging (Desprez-Loustau et al. 2010). For example, Diplodia sapinea, is an important pathogen of pines, causing various symptoms including shoot blight, canker, tip dieback, cone infections and blue stain (Swart and Wingfield 1991). It was first described in Scandinavia in 1822, but has a worldwide distribution and has caused disease losses in all pine plantation areas of the Southern Hemisphere, as well as in the USA, China and Europe (Desprez-Loustau et al. 2006). Some species of pine may suffer severe damage in non-native plantations, with the same species only being marginally affected in their natural range. Diplodia sapinea is present as a latent pathogen in healthy tissues (Bihon et al. 2011), with the incidence and severity of disease strongly correlated with stress factors (Swart and Wingfield 1991). It is probable that it was introduced to many regions with the movement of host material (Burgess and Wingfield 2002). Despite its global distribution and increasing importance under changing climatic conditions, and numerous population genetic studies using microsatellite markers (Brodde et al. 2019; Müller et al. 2019), the origin of D. sapinea remains unknown.

The problem of assigning alien status is exacerbated by the vast diversity of microbial taxa, their cryptic and inconspicuous nature, and our resultant poor knowledge of microbial communities. For example, the number of fungal species on earth is unknown, but estimates range from 1.5 to several million, the majority of which have not yet been described (Crous et al. 2015; Hawksworth and Lüking 2017). The lack of 'visibility' of microorganisms has been repeatedly provided as the reason for their absence from invasion science (Desprez-Loustau et al. 2007; Sakalidis et al. 2013; Wingfield et al. 2017; Thakur et al. 2019). Most IFPs remain undetected until visible negative impacts are observed within the recipient environment. In addition to the long lag times between arrival and detection, a diagnostics stage is required. The organism must be isolated, identified and Koch's postulates (proof of causality) fulfilled, to definitively determine the causal agent. By the time the disease problem is noticeable, and the causal agent diagnosed, the pathogen is often well established. This complicates management, and makes IFPs very difficult to contain, let alone eradicate, 
particularly once they have established in natural environments. For example, the present outbreaks of Xylella fastidiosa ssp. multiplex in Europe have been much more challenging to manage in the natural Maquis environment where it has a wide host range, than $X$. fastidiosa ssp. pauca in commercial olive groves (CoDiRO, Olive Quick Decline Syndrome) (Landa et al. 2020). Another classic example is the impact of the 'biological bulldozer' P. cinnamomi in Australia. Management of this pathogen presents greater challenges in natural ecosystems (Dunstan et al. 2010) than in avocado and other crop plants (Drenth and Guest 2004; Ramírez-Gil et al. 2017).

Microorganisms, including IFPs, have in part been overlooked in invasion science because of the vast diversity of taxa and problems relating to naming of organisms (e.g. Cowan et al. 2013; Hawksworth and Lücking 2017). For perspective, the phylogenetic "distance" amongst species of a single yeast genus, Saccharomyces, is equivalent to that between all of the known mammals and birds (Dujon 2006). This is before even considering other fungi, let alone the diversity amongst bacteria, viruses and oomycetes. It would be naïve to not acknowledge that within this vast diversity of organisms, very different biological strategies must exist for microbial invaders. This is in contrast to the move to unify into a single treatment the frameworks for studying all invasions, and it potentially dilutes our ability to address these invasions effectively (Wingfield et al. 2017). For example, Burgess and Wingfield (2017) identified seven different scenarios to account for how diseases of one genus, Eucalyptus, have moved and established within Australia and globally. Consequently, a framework for IFPs requires a nuanced approach to accommodate the overarching role of the environment in the outcome of novel interactions between hosts and pathogens.

A further confounding factor faced by forest pathologists is the challenge of accurate identification of microorganisms. Only in the last 30 years has there been a shift from the use of morphology-based to evolutionary biology-based species concepts (Harrington and Rizzo 1999; Taylor et al. 2000). Recent developments in molecular technologies and phylogenetic analysis have facilitated species identification at a much higher resolution than that based on morphology. There are now many examples of morphologically identical cryptic species that, without the application of DNA sequencing techniques, would never have been delineated as different species. For example, it was originally thought the pathogen causing cankers of Eucalyptus in South Africa belonged to the same genus as the fungus devastating chestnuts, Cryphonectria parasitica. It has since been determined, through the use of DNA-based technologies, that the disease on Eucalyptus can be caused by four different species, all belonging to the distantly related genus Chrysoporthe (Gryzenhout et al. 2004).

Name-based biosecurity will remain challenging for microorganisms. Disagreements regarding definitions of species present a confounding factor, and genetic diversity in microbe populations (with various genetic strains or mating types showing variation in virulence or host range) cannot be accounted for under a name-based approach (McTaggart et al. 2016). Rapid molecular diagnostics (Luchi et al. 2020), advances in high throughput sequencing (Hamelin and Roe 2019) and studies of microbial diversity in poorly explored ecosystems (Tedersoo et al. 2014; Desprez-Loustau et al. 
2016) are areas of research with the potential to enhance our ability to better predict and prevent future invasions, and should continue to be pursued.

While there is an obvious lack of knowledge regarding the biodiversity, ecology, speciation and geographic origin of many IFPs, of all the categories of microorganisms, pathogens (including IFPs) are amongst those most widely studied. Information concerning the status (native or alien) is even less known for many other groups of microbes. The impacts of non-pathogenic microorganisms, including endophytes, saprophytes and mycorrhizal fungi, are less apparent than those of pathogens. Despite this, these microorganisms may still affect important ecosystems functions, and likely play an important role in facilitating invasions by other taxa. There has been a growing acknowledgement of the importance of studying and understanding these invasions (see Desprez-Loustau et al. 2007; Litchman 2010; Gladieux et al. 2015; Crous et al. 2016; Dickie et al. 2017; Thakur et al. 2019).

\section{Towards a framework for forest pathogens}

Within the discipline of invasion science, researchers studying different taxonomic groups and different environments have developed separate ways of investigating IASs. There have been efforts to reconcile these differences (see Blackburn et al. 2011; Gurevitch et al. 2011; Thomsen et al. 2011), however, forest pathologists (even more broadly microbiologists) are generally absent as authors from the literature in which the frameworks most widely used for studying invasions have been proposed. For example, the Blackburn et al. (2011) unified framework is predominantly focussed on animal and plant invasions. Wingfield et al. (2017) presented a response to this framework from a forest fungal pathogen perspective, highlighting the important issues relevant to understanding invasions by IFPs. Furthermore, how these are poorly understood and typically poorly considered in general invasion science literature. IFPs are essentially a subset of IASs (microorganisms causing disease on woody plants), and a subset of EIDs (those that establish by human mediated introduction). The terminology and frameworks of EIDs (e.g. Hatcher et al. 2012; Dunn and Hatcher 2015) and IASs (e.g. Blackburn et al. 2011) should thus both be explored to inform our understanding of the invasion process of forest pathogens. While microorganisms present a unique set of challenges with regard to being understood as IAS, acknowledging these challenges will assist in modifying frameworks to accommodate IFPs.

\section{Microorganisms as invaders}

Where microorganisms have been considered by invasion scientists, e.g. Blackburn and Ewen (2017), the focus has often been on microorganisms as "drivers" or "passengers" of invasions, rather than as invaders in their own right. Many types of microorganisms play crucial roles in alien plant invasions (Traveset and Richardson in press). For ex- 
ample, the novel weapon hypothesis (NWH), proposed by Price et al. (1986), suggests that when an alien host arrives with a coevolved benign organism (e.g. endophyte or latent pathogen), such an alien organism may infect native host species in the recipient environment. If the organism negatively impacts the native host to a point where it is considered to have increased the likelihood of its alien host's establishment, then it can be considered a novel weapon.

Within the field of infectious diseases, the process by which a coevolved organism infects a novel host may be viewed as a type of "spill-over". The concept was developed within the context of animal and human pathology (Daszek et al. 2000), however, has subsequently also been applied to plant pathogens (Power and Mitchell 2004; Blitzer et al. 2012). Spill-over may, however, occur independently of conferring advantage to the alien host, and is thus not strictly linked to the NWH. For example, the invasion by the chestnut blight pathogen, $C$. parasitica, devastated American chestnut populations, but did not favour the invasiveness or facilitate the establishment of Asian chestnut species with which it arrived. In forest pathology the mechanism by which microorganisms arrive as "hitchhikers" on asymptomatic germplasm, and move to novel hosts (as a result of human-mediated introductions) has rather been considered under the term "host-jump" (Slippers et al. 2005; Burgess et al. 2016).

\section{Pathways of introduction}

The introduction of microorganisms (including IFPs) to novel regions generally occurs via the two categories of unintentional transport: "contaminant" and "stowaway", as classified in the Convention on Biological Diversity categorisation of pathways of introduction (CBD 2014). Within this categorisation, it is specified that organisms transported as contaminants interact directly with the commodity, while stowaways use a vector to move between locations, without interacting with this vector (Harrower et al. 2018). Putative pathogens such as those belonging to the genus Phytophthora may be transported with potted plants (Migliorini et al. 2015), either as stowaways (present in the soil but without interacting with the plant), or as contaminants (should they be biologically linked to the plant). They may also be transported via more obscure means, such as stowaways in soil transported with traded used cars (Ridley et al. 2000). The term "hitchhiker" is used by forest pathologists to refer to microorganisms transported with asymptomatic plants, which would align it with the "contaminant" pathway - specifically the sub-category "parasites on plants" (Burgess et al. 2016). However, the term "hitchhiker" in invasion science, precludes biological connection to the organism with which they are transported, and only occurs in the "stowaway" category. Further, the use of the term "contaminant", is arguably inappropriate for microorganisms present as endophytes or in other symbiotic relationships with their hosts. Despite the efforts to accommodate IFPs in the CBD pathway categorisation, there is a need to better harmonise the terminologies used in the two fields (cf. Faulkner et al. 2020 for a broader critique of the CBD pathway categorisation). 


\section{Impacts}

Studies of impacts of IFPs have often focussed on effects on other trophic levels (e.g. the impacts of Phytophthora cinnamomi on vegetation structure), as this is where negative impacts are most readily observed (Desprez-Loustau et al. 2007). The impacts of IFPs on microbial communities is a deeply understudied area. One example illustrating the potential for impacts at the same trophic level comes from studies of the invasion by the aggressive IFP Hymenoschyphus fraxineus (causal agent of ash dieback). Following invasion, $H$. fraxineus replaces the native decomposer $H$. albidus (McKinney et al. 2012). Another interesting example is the new invader Ophiostoma novo-ulmi completely replacing the less aggressive and old invader Ophiostoma ulmi in Europe (Brasier 1998). Thakur et al. (2019) proposed a "network" approach to provide a better understanding of interactions among species at different trophic levels, following establishment of alien microorganisms. Monitoring such interactions over long time scales will enhance our ability to understand the dynamics and impacts of IFPs on hosts, communities and ecosystems (Thakur et al. 2019).

Examining the long-term impacts of invasions e.g. level of impact, extent and rate of spread, may provide insights into pathogen or environment traits linked to the outcome of the invasion. A well-documented example is that of oak powdery mildew in Europe. Desprez-Loustau et al. (2019) describe the ecological and evolutionary trajectory of this pathogen complex over the course of a century. This, from its initial impact characterised by severe damage typical of pathogen invasion dynamics (with disease epidemics resulting in tree mortality), to the current equilibrium between host and pathogen, which has resulted in decreased disease severity. Desprez-Loustau et al. (2019) utilise a modelling approach to investigate the eco-evolutionary dynamics of the oak powdery mildew pathosystem, and highlight the value of such systems to explore the evolution of virulence and resistance following invasions, in the context of changing environments.

A consolidated effort is required to move from studies of interactions between individual species to those at the community level. Perhaps this can be achieved by the network approach proposed by Thakur et al. (2019), or through landscape epidemiology, a recently developed field that merges concepts of disease epidemiology with landscape ecology (Holdenrieder 2004; Lundquist and Hamelin 2005; Meentemeyer et al. 2012). This discipline links molecular and microbial observations of disease distribution with measurements of biotic and abiotic conditions, incorporating spatiotemporal complexity in epidemiological systems at the landscape level. Further, Oliva et al. (2020) proposed the development of a functional ecology approach to forest pathology, focussing on building functional trait databases to assist forest pathologists in dealing with the increasingly complex problems posed by forest pathogens under global change.

\section{Eradication feasibility}

There are numerous examples of successful eradication of plant pathogens from manmade settings, particularly in controlled environments such as greenhouses (Pluess et 
al. 2012). However, eradication of established IFPs in natural ecosystems is incredibly challenging, and the few successful cases of IFP eradication known globally were achieved prior to spread into natural ecosystems. For example, fire blight is a destructive and highly infectious disease of apples, pears and other members of the family Rosaceae, caused by the bacterium Erwinia amylovora. In 1997, fire blight was detected in Australia, at the Royal Botanic Gardens, Melbourne (Jock et al. 2000). Following this detection, an intensive eradication and surveillance programme was undertaken, leading to successful eradication (Rodoni et al. 2006). Fusarium circinatum, a fungal pathogen that causes pitch canker disease of pine (Gordon 2006; Wingfield et al. 2008), is considered to be one of the most important pathogens affecting Pinus seedlings and mature trees in many countries. Fusarium circinatum outbreaks have been officially eradicated in France and Italy, with the success of the eradication efforts attributed to early detection, constant surveillance and control measures (Vainio et al. 2019). In each of these examples, eradication was likely only possible due to detection in the very early stages of establishment, with outbreaks confined to urban environments such as gardens, parks and nurseries. The earlier diseases are detected, and management interventions initiated, the greater the likelihood that eradication or containment measures will be successful, and at lower economic and environmental cost (Luchi et al. 2020).

The examples of the fire blight and pitch canker diseases were of pathogens wellknown elsewhere in the world. Consequently, they were relatively easily recognised when they first appeared and techniques and tools for identification were well-established, facilitating rapid diagnostics. This is very different in the case of tree diseases of unknown cause such as pine wilt caused by the pine wood nematode (Bursaphelenchus xylophilus), or sudden oak death caused by P. ramorum; both took many years, in the former case decades, before the causal agents became known (Mamiya 1983; Fielding and Evans 1996; Werres et al. 2001). A recent example demonstrating the issues arising from knowledge gaps in fungal diversity, exacerbated by limited surveillance, is that of ash dieback in Europe. The first reports of dieback were from Poland in the early 1990s; however, it was not until 2006 that the cause of mortality was found to be a biotic agent, Chalara fraxinea (Pautasso et al. 2013). Initially, this anamorphic fungus was linked morphologically to a saprotrophic leaf colonising ascomycete, Hymenoschyphus albidus. This species was long known in Europe, but not as a fungus causing disease. Only five years later did molecular investigations show the teleomorph of $C$. fraxinea was actually a previously undescribed cryptic species (Queloz et al. 2011), the IFP $H$. fraxineus. This long delay in recognising the alien origin of the fungus precluded its inclusion in quarantine lists. By the time its alien status was recognised, the pathogen and resulting ash mortality had already reached many other European countries.

\section{Horizon scanning}

There are many examples of IFPs that were not known to cause disease, and others even unknown to science, prior to their establishment in a novel environment (Brasier 
2008; Wingfield et al. 2015). This lack of baseline information presents major challenges with regards to predicting the next microbial invader, and constrains our ability to undertake pest risk analysis (Roy et al. 2017). Horizon scanning (systematic examination of potential threats and opportunities) presents an opportunity to prioritise actions and identify knowledge gaps (Roy et al. 2017). The IUCN Environmental Impact Classification for Alien Taxa (EICAT) is a horizon scanning tool developed as an objective framework for the assessment of all taxa (Hawkins et al. 2015; Kumschick et al. 2020). Mechanism 5 of the framework provides for classification of impact by parasites and pathogens, however, the framework has, to the best of our knowledge, not yet been applied to any IFPs, either by forest pathologists or invasion scientists.

Eschen et al. (2019) proposed the concept of ex-patria sentinel plantings (sentinel plantations), i.e. species native to a plant importing continent growing in an exporting one, monitoring these plants can lead to the identification of novel pathogen-host associations; and of in-patria sentinel plantings (sentinel nurseries), i.e. species native to the exporting continent, growing in their own continent. Identification of native pesthost associations provide information for the risk of introducing harmful organisms through the trade of plant commodities. Such efforts contribute relevant information to gap fill pest risk analysis, and can aid the development of measures to mitigate introduction risks (Britton et al. 2010; Eschen et al. 2019).

\section{Conclusion}

The paucity of knowledge for many aspects of microorganisms has presented challenges to understanding them as IASs, and has likely led to their underrepresentation in the invasion science literature. Advances in molecular techniques have provided powerful tools with which to study IFPs. This arises as techniques make it possible to identify pathogens more easily and accurately, greatly enhancing our knowledge of these organisms and their biogeography and ecology. Hamelin and Roe (2019) and Luchi et al. (2020) provide comprehensive reviews of advances in molecular methods and genomic tools, and their potential applications for bio-surveillance. However, forest pathologists need to be sure to ask the appropriate questions, if they are to adequately apply these tools, and this relies on an understanding of ecology (Zinger et al. 2019).

Technologies are advancing rapidly, and are commonly ahead of available knowledge of the pathogen systems being studied. Consequently, there is a risk for incorrect assumptions to be made due to poor sampling strategies (Zinger et al. 2019). Thus, forest pathologists should more actively apply ecological concepts to the pathosystems they study. High-throughput molecular techniques may contain sequencing errors, lack of replication, experimental contamination and PCR (primer) induced biases are all potential pitfalls requiring consideration (Dickie 2010; Zinger et al. 2019). There are, however, now a number of examples where newly developed molecular tools have been successfully utilised to investigate pathways of introduction and spread of IFPs (e.g. Dutech et al. 2012; Garbelotto et al. 2013; Gross et al. 2014; Landa et al. 2020). 
Trees live for very long periods and can be exposed to pathogens over their lifespan. They establish complex interactions among both beneficial and detrimental microorganisms including those that make up their microbiomes (Kemler et al. 2013; Thompson et al. 2017). Therefore, a more ecological, rather than a purely mechanistic approach, needs to be applied to the study of tree pathosystems. Equally, the role of microorganisms as invasives, as well as in influencing the invasibility of environments, must become an area of research focus within invasion science. In addition to the arrival of IFPs, the health and resilience of forest ecosystems worldwide is being impacted by global change factors including climate and land use change and increased pollution. The effects of forest disturbances (wildfires, droughts, storms, pest and pathogen outbreaks) will be altered under these conditions, with the potential for increased vulnerability to IFPs. A rise in complex diseases and tree declines under global change is a major challenge facing forest pathologists (Anderson et al. 2004; Desprez-Loustau et al. 2006; Pautasso et al. 2015; Trumbore et al. 2015; Ghelardini et al. 2016).

Invasions by pathogens into forest ecosystems lead to the decline and loss of keystone species, resulting in irreversible impacts. By not using the terminology of invasion science, and by remaining disconnected from the frameworks developed and used to study biological invasions, much of the work of forest pathologists has been ignored by the wider invasion science community. Aligning terminologies and experimental designs with those utilised by invasion scientists will allow forest pathologists to reach a larger audience, in turn generating opportunities for collaboration.

For well-studied pathosystems, forest pathologists have a deep understanding of the biology of the organisms they work with. This adds layers of complexity, but also allows for more nuanced explanations. The disease triangle is a central component of plant pathology, illustrating the interactions between a host, a pathogen, and an environment - the three key aspects determining the extent to which disease will develop. This approach may also bring benefits to invasion ecology. For example, Perkins et al. (2011) proposed an adaptation in the form of the invasion triangle, incorporating the three components - the invader, site biotic characteristics, and environmental conditions of the site, as a tool for understanding and predicting why species are invasive in specific environments.

Microorganisms are gaining greater attention in the field of invasion science. As noted by Ricciardi et al. (2017), microbial ecology is becoming increasingly relevant to understanding and managing invasions. These organisms cannot be ignored. They constitute important components of all ecosystems, and are a vital part of community ecology and ecosystem functioning, as well as representing an important component of IASs. In the same way that disturbance may facilitate invasions (Wilson et al. 2020), IFPs play a considerable role in modifying ecosystems. And where a native forest species is functionally eliminated from an ecosystem following the establishment of a high impact IFP, an empty niche remains, with the potential for this to be filled by an alien plant species.

There has been a recent call for pathologists and entomologists to work together in response to the rising threat to forests posed by invasive pests and pathogens (Jactel et al. 
2020). The authors argue that while traditionally considered separate disciplines, many tools and conceptual frameworks underpinning pathology and entomology can and should be shared, to meet the common goal of improved forest protection. Similarly, Nunez et al. (2020) proposed the strengthening of collaborations between ecologists, epidemiologists, sociologists, and biomedical researchers, to develop an expanded invasion science discipline (see also Hulme et al. 2020). Such an approach, embedded in the philosophy of the "One Health" concept recognising the interrelatedness of human, animal and ecosystem health (Xie et al. 2017), has the potential to make meaningful contributions to global biosecurity.

Against this background, a unified framework inclusive of IFPs should be designed. This should incorporate the basis of existing frameworks but also acknowledge and accommodate their shortfalls. This approach will facilitate the establishment of a more inclusive and a truly unified framework in the future (Wilson et al. 2020b). Clearly, the continued promotion and application of multiple disciplinary approaches to forest pathology and invasion science research is critical, if we are to adequately understand and address the complex challenges of identifying and managing forest pathogen invasions.

\section{Acknowledgements}

This paper emerged from a workshop on 'Frameworks used in Invasion Science' hosted by the DSI-NRF Centre of Excellence for Invasion Biology in Stellenbosch, South Africa, 11-13 November 2019, that was supported by the National Research Foundation of South Africa and Stellenbosch University. We thank the three reviewers, whose suggestions have enabled us to greatly improve the originally submitted manuscript.

\section{References}

Anderson PK, Cunningham AA, Patel NG, Morales FJ, Epstein PR, Daszak P (2004) Emerging infectious diseases of plants: pathogen pollution, climate change and agrotechnology drivers. Trends in Ecology \& Evolution 19: 535-544. https://doi.org/10.1016/j.tree.2004.07.021 Bihon W, Burgess TI, Slippers B, Wingfield MJ, Wingfield BD (2011) Distribution of Diplodia pinea and its genotypic diversity within asymptomatic Pinus patula trees Australasian Plant Pathology 40: 540-548. https://doi.org/10.1007/s13313-011-0060-z

Blackburn TM, Ewen JG (2017) Parasites as drivers and passengers of human-mediated biological invasions. EcoHealth 14: 61-73. https://doi.org/10.1007/s10393-015-1092-6

Blackburn TM, Pyšek P, Bacher S, Carlton JT, Duncan RP, Jarošík V, Wilson JRU, Richardson DM (2011) A proposed unified framework for biological invasions. Trends in Ecology \& Evolution 26: 333-339. https://doi.org/10.1016/j.tree.2011.03.023

Blitzer EJ, Dormann CF, Holzschuh A, Klein AM, Rand TA, Tscharntke T (2012) Spillover of functionally important organisms between managed and natural habitats. Agriculture, Ecosystems \& Environment 146: 34-43. https://doi.org/10.1016/j.agee.2011.09.005 Boyce JS (1938) Forest Pathology. McGraw-Hill, London, 600 pp. 
Brasier CM (2008) The biosecurity threat to the UK and global environment from international trade in plants. Plant Pathology 57: 792-808. https://doi.org/10.1111/j.13653059.2008.01886.x

Brasier CM, Buck KW (2001) Rapid evolutionary changes in a globally invading fungal pathogen (Dutch elm disease). Biological Invasions 3: 223-233. https://doi. org/10.1023/A:1015248819864

Brasier CM, Kirk SA, Pipe ND, Buck KW (1998) Rare interspecific hybrids in natural populations of the Dutch elm disease pathogens Ophiostoma ulmi and O. novo-ulmi. Mycological Research 102: 45-57. https://doi.org/10.1017/S0953756297004541

Brasier CM, Beales PA, Kirk SA, Denman S, Rose J (2005) Phytophthora kernoviae sp. nov., an invasive pathogen causing bleeding stem lesions on forest trees and foliar necrosis of ornamentals in the UK. Mycological Research 109: 853-859. https://doi.org/10.1017/S0953756205003357

Britton KO, White P, Kramer A, Hudler G (2010) A new approach to stopping the spread of invasive insects and pathogens: early detection and rapid response via a global network of sentinel plantings. New Zealand Journal of Forestry Science 40: 109-114.

Brodde L, Adamson K, Julio Camarero J, Castańo C, Drenkhan R, Lehtijärvi A, Luchi N, Migliorini D, Sánchez-Miranda Á, Stenlid J, Özdağ, Ş, Oliva J (2019) Diplodia tip blight on its way to the north: drivers of disease emergence in northern Europe. Frontiers in Plant Science 9: 1818. https://doi.org/10.3389/fpls.2018.01818

Burdon JJ, Thrall PH (2009) Coevolution of plants and their pathogens in natural habitats. Science 324: 755-756. https://doi.org/10.1126/science.1171663

Burgess TI, Wingfield MJ (2002) Quarantine is important in restricting the spread of exotic seed-borne tree pathogens in the Southern Hemisphere. International Forestry Review 4: 56-65. https://www.jstor.org/stable/43740945

Burgess TI, Wingfield MJ (2017) Pathogens on the move: a 100-year global experiment with planted eucalypts. Bioscience 67: 14-25. https://doi.org/10.1093/biosci/biw146

Burgess TI, Crous CJ, Hantula J, Slippers B, Wingfield MJ (2016) Tree invasions and biosecurity: eco-evolutionary dynamics of hitchhiking fungi. AoB Plants 8: plw076. https://doi. org/10.1093/aobpla/plw076

Cadotte M, Yasui SLE, Livingstone S, MacIvor JS (2017) Are urban systems beneficial, detrimental, or indifferent to species invasion? Biological Invasions 19: 3489-3503. https://doi.org/10.1007/s10530-017-1586-y

Cobb RC, Filipe JA, Meentemeyer RK, Gilligan CA, Rizzo DM (2012) Ecosystem transformation by emerging infectious disease: loss of large tanoak from California forests. Journal of Ecology 100: 712-722. https://doi.org/10.1111/j.1365-2745.2012.01960.x

Coker TLR, Rozsypálek J, Edwards A, Harwood TP, Butfoy L, Buggs RJA (2019) Estimating mortality rates of European ash (Fraxinus excelsior) under the ash dieback (Hymenoscyphus fraxineus) epidemic. Plants, People, Planet 1: 48-59. https://doi.org/10.1002/ppp3.11

Convention on Biological Diversity (CBD) (2014) Pathways of introduction of invasive species, their prioritization and management. https://www.cbd.int/doc/meetings/sbstta/sbstta-18/ official/sbstta-18-09-add1-en.pdf

Courchamp F, Fournier A, Bellard C, Bertelsmeier C, Bonnaud E, Jeschke JM, Russell JC (2017) Invasion biology: specific problems and possible solutions. Trends in Ecology \& Evolution 32: 13-22. https://doi.org/10.1016/j.tree.2016.11.001 
Coutinho TA, Wingfield MJ, Alfenas AC, Crous PW (1998) Eucalyptus Rust: A Disease with the Potential for Serious International Implications. Plant Disease 82: 819-825. https:// doi.org/10.1094/PDIS.1998.82.7.819

Cowan DA, Rybicki EP, Tuffin MI, Valverde A, Wingfield MJ (2013) Biodiversity: so much more than legs and leaves. South African Journal of Science 109: a0037. https://doi. org/10.1590/sajs.2013/a0037

Crous PW, Hawksworth DL, Wingfield MJ (2015) Identifying and naming plant-pathogenic fungi: Past, present and future. Annual Review of Phytopathology 53: 247-267. https:// doi.org/10.1146/annurev-phyto-080614-120245

Crous PW, Groenewald JZ, Slippers B, Wingfield MJ (2016) Global food and fibre security threatened by current inefficiencies in fungal identification. Philosophical Transactions of the Royal Society B 371: 20160024. https://doi.org/10.1098/rstb.2016.0024

Daszak P, Cunningham AA, Hyatt AD (2000) Emerging infectious diseases of wildlife-threats to biodiversity and human health. Science 287: 443-449. https://doi.org/10.1126/ science.287.5452.443

Desprez-Loustau ML, Hamelin F, Marçais B (2019) The ecological and evolutionary trajectory of oak powdery mildew in Europe. In: Wilson K, Fenton A, Tompkins D (Eds) Wildlife Disease Ecology: Linking Theory to Data and Application (Ecological Reviews). Cambridge University Press (Cambridge): 429-457. https://doi.org/10.1017/9781316479964.015

Desprez-Loustau ML, Marçais B, Nageleisen LM, Piou D, Vannini A (2006) Interactive effects of drought and pathogens in forest trees. Annals of Forest Science 63: 597-612. https:// doi.org/10.1051/forest:2006040

Desprez-Loustau ML, Robin C, Buee M, Courtecuisse R, Garbaye J, Suffert F, Sache I, Rizzo D (2007) The fungal dimension of biological invasions. Trends in Ecology \& Evolution 22: 472-480. https://doi.org/10.1016/j.tree.2007.04.005

Desprez-Loustau ML, Courtecuisse R, Robin C, Husson C, Moreau PA, Blancard D, Selosse MA, Lung-Escarmant B, Piou D, Sache I (2010) Species diversity and drivers of spread of alien fungi (sensu lato) in Europe with a particular focus on France. Biological Invasions 12: 157-172. https://doi.org/10.1007/s10530-009-9439-y

Desprez-Loustau ML, Aguayo J, Dutech C, Hayden KJ, Husson C, Jakushkin B, Marçais B, Piou D, Robin C, Vacher C (2016) An evolutionary ecology perspective to address forest pathology challenges of today and tomorrow. Annals of Forest Science 73: 45-67. https:// doi.org/10.1007/s13595-015-0487-4

Dickie IA (2010) Insidious effects of sequencing errors on perceived diversity in molecular surveys. New Phytologist 188: 916-918. https://doi.org/10.1111/j.1469-8137.2010.03473.x

Dickie IA, Bufford JL, Cobb RC, Desprez-Loustau ML, Grelet G, Hulme PE, Klironomos J, Makiola A, Nuñez MA, Pringle A, Thrall PH (2017) The emerging science of linked plantfungal invasions. New Phytologist 215: 1314-1332. https://doi.org/10.1111/nph.14657

Drenth A, Guest DI (2004) 7.1 Principles of phytophthora disease management. In: Drenth A, Guest DI (Eds) Diversity and management of Phytophthora in Southeast Asia. ACIAR Monograph 114 (Canberra): 154-160.

Dujon B (2006) Yeasts illustrate the molecular mechanisms of eukaryotic genome evolution. Trends in Genetics 22: 375-387. https://doi.org/10.1016/j.tig.2006.05.007 
Dukes JS, Pontius J, Orwig D, Garnas JR, Rodgers VL, Brazee N, Cooke B, Theoharides KA, Stange EE, Harrington R, Ehrenfeld J (2009) Responses of insect pests, pathogens, and invasive plant species to climate change in the forests of northeastern North America: What can we predict? Canadian Journal of Forest Research 39: 231-248. https://doi.org/10.1139/X08-171

Dunn AM, Hatcher MJ (2015) Parasites and biological invasions: parallels, interactions, and control. Trends in Parasitology 31:189-199. https://doi.org/10.1016/j.pt.2014.12.003

Dunstan WA, Rudman T, Shearer BL, Moore NA, Paap T, Calver MC, Dell B, Hardy GE (2010) Containment and spot eradication of a highly destructive, invasive plant pathogen (Phytophthora cinnamomi) in natural ecosystems. Biological Invasions 12: 913-925. https://doi.org/10.1007/s10530-009-9512-6

Dutech C, Barrès B, Bridier J, Robin C, Milgroom MG, Ravigné V (2012) The chestnut blight fungus world tour: successive introduction events from diverse origins in an invasive plant fungal pathogen. Molecular Ecology 21: 3931-3946. https://doi.org/10.1111/j.1365294X.2012.05575.x

Elton CS (1958) The ecology of invasions by animals and plants. Methuen, London, 181 pp. https://doi.org/10.1007/978-1-4899-7214-9

Eschen R, O’Hanlon R, Santini A, Vannini A, Roques A, Kirichenko N, Kenis M (2019) Safeguarding global plant health: the rise of sentinels. Journal of Pest Science 92: 29-36. https://doi.org/10.1007/s10340-018-1041-6

Eschen R, Britton K, Brockerhoff E, Burgess T, Dalley V, Epanchin-Niell RS, Gupta K, Hardy G, Huang Y, Kenis M, Kimani E (2015) International variation in phytosanitary legislation and regulations governing importation of plants for planting. Environmental Science \& Policy 51: 228-237. https://doi.org/10.1016/j.envsci.2015.04.021

European Union (2019) Commission Implementing Regulation (EU) 2019/1262 of 25 July 2019 amending Implementing Regulation (EU) 2016/1141 to update the list of invasive alien species of Union concern. https:/ec.europa.eu/environment/nature/invasivealien/ docs/R_2016_1141_Union-list-2019-consolidation.pdf.

Faulkner KT, Hulme PE, Pagad S, Wilson JRU, Robertson MP (2020) Classifying the introduction pathways of alien species: are we moving in the right direction? In: Wilson JR, Bacher S, Daehler CC, Groom QJ, Kumschick S, Lockwood JL, Robinson TB, Zengeya TA, Richardson DM (Eds) Frameworks used in Invasion Science. NeoBiota 62: 143-159. https://doi.org/10.3897/neobiota.62.53543

Fernandez Winzer L, Cuddy W, Pegg GS, Carnegie AJ, Manea A, Leishman MR (2020) Plant architecture, growth and biomass allocation effects of the invasive pathogen myrtle rust (Austropuccinia psidii) on Australian Myrtaceae species after fire. Austral Ecology 45: 177186. https://doi.org/10.1111/aec.12845

Fielding NJ, Evans HF (1996) The pine wood nematode Bursaphelenchus xylophilus (Steiner and Buhrer) Nickle (= B. lignicolus Mamiya and Kiyohara): an assessment of the current position. Forestry: An International Journal of Forest Research 69: 35-46. https://doi. org/10.1093/forestry/69.1.35

Fisher MC, Henk DA, Briggs CJ, Brownstein JS, Madoff LC, McCraw SL, Gurr SJ (2012) Emerging fungal threats to animal, plant and ecosystem health. Nature 484: 186-194. https://doi.org/10.1038/nature10947 
Foxcroft LC, Pyšek P, Richardson DM, Genovesi P, MacFadyen S (2017) Plant invasion science in protected areas: progress and priorities. Biological Invasions 19: 1353-1378. https://doi. org/10.1007/s10530-016-1367-z

Garbelotto M, Guglielmo F, Mascheretti S, Croucher PJ, Gonthier P (2013) Population genetic analyses provide insights on the introduction pathway and spread patterns of the North American forest pathogen Heterobasidion irregulare in Italy. Molecular Ecology 22: 4855-4869. https://doi.org/10.1111/mec.12452

Ghelardini L, Pepori AL, Luchi N, Capretti P, Santini A (2016) Drivers of emerging fungal diseases of forest trees. Forest Ecology and Management 381: 235-246. https://doi. org/10.1016/j.foreco.2016.09.032

Ghelardini L, Luchi N, Pecori F, Pepori AL, Danti R, Della Rocca G, Capretti P, Tsopelas P, Santini A (2017) Ecology of invasive forest pathogens. Biological Invasions 19: 31833200. https://doi.org/10.1007/s10530-017-1487-0

Giraud T, Gladieux P, Gavrilets S (2010) Linking the emergence of fungal plant diseases with ecological speciation. Trends in Ecology \& Evolution 25: 387-395. https://doi. org/10.1016/j.tree.2010.03.006

Gladieux P, Guérin F, Giraud T, Caffier V, Lemaire C, Parisi L, Didelot F, Le Cam B (2011) Emergence of novel fungal pathogens by ecological speciation: importance of the reduced viability of immigrants. Molecular Ecology 20: 4521-4532. https://doi.org/10.1111/ j.1365-294X.2011.05288.x

Glen M, Alfenas AC, Zauza EAV, Wingfield MJ, Mohammed C (2007) Puccinia psidii: a threat to the Australian environment and economy-a review. Australasian Plant Pathology 36: 1-16. https://doi.org/10.1071/AP06088

Gordon TR (2006) Pitch canker disease of pines. Phytopathology 96: 657-659. https://doi. org/10.1094/PHYTO-96-0657

Gross A, Hosoya T, Queloz V (2014) Population structure of the invasive forest pathogen Hymenoscyphus pseudoalbidus. Molecular Ecology 23: 2943-2960. https://doi.org/10.1111/ mec. 12792

Gryzenhout M, Myburg H, Van der Merwe NA, Wingfield BD, Wingfield MJ (2004) Chrysoporthe, a new genus to accommodate Cryphonectria cubensis. Studies in Mycology 50: 119-142.

Gurevitch J, Fox GA, Wardle GM, Taub D (2011) Emergent insights from the synthesis of conceptual frameworks for biological invasions. Ecology Letters 14: 407-418. https://doi. org/10.1111/j.1461-0248.2011.01594.x

Hamelin RC, Roe AD (2019) Genomic biosurveillance of forest invasive alien enemies: A story written in code. Evolutionary Applications 13: 95-115. https://doi.org/10.1111/ eva. 12853

Harrington TC, Rizzo DM (1999) Defining species in the fungi. In: Worrall JJ (Eds) Structure and Dynamics of Fungal Populations. Springer, Dordrecht, 43-71. https://doi. org/10.1007/978-94-011-4423-0_3

Harrower CA, Scalera R, Pagad S, Schonrogge K, Roy HE (2018) Guidance for interpretation of CBD categories on introduction pathways. Technical note prepared by IUCN for the European Commission. CEH Project no. C06225: 1-100. 
Hatcher MJ, Dick JT, Dunn AM (2012) Disease emergence and invasions. Functional Ecology 26: 1275-1287. https://doi.org/10.1111/j.1365-2435.2012.02031.x

Hawkins CL, Bacher S, Essl F, Hulme PE, Jeschke JM, Kühn I, Kumschick S, Nentwig W, Pergl J, Pyšek P, Rabitsch W, Richardson DM, Vilà M, Wilson JRU, Genovesi P, Blackburn TM (2015) Framework and guidelines for implementing the proposed IUCN Environmental Impact Classification for Alien Taxa (EICAT). Diversity and Distributions 21: 1360-1363. https://doi.org/10.1111/ddi.12379

Hawksworth DL, Lücking R (2017) Fungal Diversity Revisited: 2.2 to 3.8 Million Species. In: Heitman J, Howlett BJ, Crous PW, Stukenbrock EH, James TY, Gow NAR (Eds) The Fungal Kingdom. https://doi.org/10.1128/9781555819583.ch4

Holdenrieder O (2004) Tree diseases and landscape processes: the challenge of landscape pathology. Trends in Ecology \& Evolution 19: 446-452. https://doi.org/10.1016/j. tree.2004.06.003

Hui C, Richardson DM (2017) Invasion dynamics. Oxford University Press (Oxford): 1-322. https://doi.org/10.1093/acprof:oso/9780198745334.001.0001

Hulme PE, Baker R, Freckleton R, Hails RS, Hartley M, Harwood J, Marion G, Smith GC, Williamson M (2020) The Epidemiological Framework for Biological Invasions (EFBI): an interdisciplinary foundation for the assessment of biosecurity threats. In: Wilson JR, Bacher S, Daehler CC, Groom QJ, Kumschick S, Lockwood JL, Robinson TB, Zengeya TA, Richardson DM (Eds) Frameworks used in Invasion Science. NeoBiota 62: 161-192. https://doi.org/10.3897/neobiota.62.52463

Hunter GC, van der Merwe NA, Burgess TI, Carnegie AJ, Wingfield BD, Crous PW, Wingfield MJ (2008) Global movement and population biology of Mycosphaerella nubilosa infecting leaves of cold-tolerant Eucalyptus globulus and E. nitens. Plant Pathology 57: 235-242. https://doi.org/10.1111/j.1365-3059.2007.01756.x

Jactel H, Desprez-Loustau ML, Battisti A, Brockerhoff E, Santini A, Stenlid J, Bjorkman C, Branco M, Dehnen-Schmutz K, Douma JC, Drakulic J, Drizou F, Eschen R, Franco JC, Gossner MM, Green S, Kenis M, Klapwijk MJ, Liebhold AM, Orazio C, Prospero S, Robinet C, Schroeder M, Slippers B, Stoev P, Sun J, van den Dool R, Wingfield MJ, Zalucki MP (2020) Pathologists and entomologists must join forces against forest pest and pathogen invasions. NeoBiota 58: 107-127. https://doi.org/10.3897/ neobiota.58.54389

Jock S, Rodoni B, Gillings M, Kim WS, Copes C, Merriman Geider K (2000) Screening of ornamental plants from the Botanic Gardens of Melbourne and Adelaide for the occurrence of Erwinia amylovora. Australasian Plant Pathology 29: 120-128. https://doi.org/10.1071/ AP00020

Jules ES, Kauffman MJ, Ritts WD, Carroll AL (2002) Spread of an invasive pathogen over a variable landscape: a nonnative root rot on Port Orford cedar. Ecology 83: 3167-3181. https://doi.org/10.1890/0012-9658(2002)083[3167:SOAIPO]2.0.CO;2

Kemler M, Garnas J, Wingfield MJ, Gryzenhout M, Pillay K-A, Slippers B (2013) Ion Torrent PGM as tool for fungal community analysis: a case study of endophytes in Eucalyptus grandis reveals high taxonomic diversity. PLoS ONE 8(12): e81718. https://doi. org/10.1371/journal.pone.0081718 
Kutschera U, Hossfeld U (2012) Physiological phytopathology: origin and evolution of a scientific discipline. Journal of Applied Botany and Food Quality 85: 1-5.

Landa BB, Castillo AI, Giampetruzzi A, Kahn A, Román-Écija M, Velasco-Amo MP, NavasCortés JA, Marco-Noales E, Barbé S, Moralejo E, Coletta-Filho HD, Saldarelli P, Saponari M, Almeida RPP (2020) Emergence of a plant pathogen in Europe associated with multiple intercontinental introductions. Applied and Environmental Microbiology 86: e0152119. https://doi.org/10.1128/AEM.01521-19

Litchman E (2010) Invisible invaders: non-pathogenic invasive microbes in aquatic and terrestrial ecosystems. Ecology Letters 13: 1560-1572. https://doi.org/10.1111/j.14610248.2010.01544.x

Lockwood JL, Hoopes MF, Marchetti MP (2013) Invasion ecology (2 ${ }^{\text {nd }}$ edn.). Wiley-Blackwell (Oxford): 1-444.

Loo JA (2008) Ecological impacts of non-indigenous invasive fungi as forest pathogens. Biological Invasions 11: 81-96. https://doi.org/10.1007/s10530-008-9321-3

Lowe S, Browne M, Boudjelas S, De Poorter M (2000) 100 of the World's Worst Invasive Alien Species. A selection from the Global Invasive Species Database. Invasive Species Specialist Group, Auckland, 12 pp.

Luchi N, Ioos R, Santini A (2020) Fast and reliable molecular methods to detect fungal pathogens in woody plants. Applied Microbiology and Biotechnology 104: 2453-2468. https://doi.org/10.1007/s00253-020-10395-4

Lundquist JE, Hamelin RC (2005) Forest Pathology: from Genes to Landscapes. American Phytopathological Society Press, Minnesota, 175 pp.

Macdonald IAW, Kruger FJ, Ferrar AA (1986) The Ecology and Management of Biological Invasions in Southern Africa. Oxford University Press, Cape Town, 324 pp.

MacLeod A, Pautasso M, Jeger MJ, Haynes-Young R (2010) Evolution of the international regulation of plant pests and challenges for future plant health. Food Security 2: 49-70. https://doi.org/10.1007/s12571-010-0054-7

Manion PD (1981) Tree Disease Concepts. Prentice-Hall, Inc, New Jersey, 399 pp.

Mamiya Y (1983) Pathology of the pine wilt disease caused by Bursaphelenchus xylophilus. Annual Review of Phytopathology 21: 210-220. https://doi.org/10.1146/annurev. py.21.090183.001221

McKinney LV, Thomsen IM, Kjær ED, Bengtsson SBK, Nielsen LR (2012) Rapid invasion by an aggressive pathogenic fungus (Hymenoscyphus pseudoalbidus) replaces a native decomposer (Hymenoscyphus albidus): A case of local cryptic extinction? Fungal Ecology 5: 663-669. https://doi.org/10.1016/j.funeco.2012.05.004

McTaggart AR, van der Nest MA, Steenkamp ET, Roux J, Slippers B, Shuey LS, Wingfield MJ, Drenth A (2016) Fungal genomics challenges the dogma of name-based biosecurity. PLoS Pathogens 12: e1005475. https://doi.org/10.1371/journal.ppat.1005475

Meentemeyer RK, Haas SE, Václavík T (2012) Landscape epidemiology of emerging infectious diseases in natural and human-altered ecosystems. Annual Review of Phytopathology 50: 379-402. https://doi.org/10.1146/annurev-phyto-081211-172938 
Migliorini D, Ghelardini L, Tondini E, Luchi N, Santini A (2015) The potential of symptomless potted plants for carrying invasive soilborne plant pathogens. Diversity and Distributions 21: 1218-1229. https://doi.org/10.1111/ddi.12347

Mitchell RJ, Beaton JK, Bellamy PE, Broome A, Chetcuti J, Eaton S, Ellis CJ, Gimona A, Harmer R, Hester AJ, Hewison RL (2014) Ash dieback in the UK: a review of the ecological and conservation implications and potential management options. Biological Conservation 175: 95-109. https://doi.org/10.1016/j.biocon.2014.04.019

Mooney HA, Drake JA (1986) Ecology of biological invasions of North America and Hawaii. Springer Verlag, New York, 321 pp. https://doi.org/10.1007/978-1-4612-4988-7

Mooney HA, Mack RN, McNeely JA, Neville LE, Schei PJ, Waage JK (2005) Invasive alien species: a new synthesis (Vol. 63). Island Press, Washington DC, 368 pp.

Müller MM, Hantula J, Wingfield MJ, Drenkhan R (2019) Diplodia sapinea found on Scots pine in Finland. Forest Pathology 49: e12483. https://doi.org/10.1111/efp.12483

Nuñez MA, Pauchard A, Ricciardi A (2020) Invasion science and the global spread of SARS-CoV-2. Trends in Ecology \& Evolution 35: 642-645. https://doi.org/10.1016/j. tree.2020.05.004

Ogden NH, Wilson JRU, Richardson DM, Hui C, Davies SJ, Kumschick S, Le Roux JJ, Measey J, Saul WC, Pulliam JRC (2019) Emerging infectious diseases and biological invasions: a call for a One Health collaboration in science and management. Royal Society Open Science 6: 181577. https://doi.org/10.1098/rsos.181577

Oliva J, Redondo MÁ, Stenlid J (2020) Functional ecology of forest disease. Annual Review of Phytopathology 58. https://doi.org/10.1146/annurev-phyto-080417-050028

Paap T, Burgess TI, Wingfield MJ (2017a) Urban trees: bridge-heads for forest pest invasions and sentinels for early detection. Biological Invasions 19: 3515-3526. https://doi. org/10.1007/s10530-017-1595-x

Paap T, Brouwers NC, Burgess TI, Hardy GE (2017b) Importance of climate, anthropogenic disturbance and pathogens (Quambalaria coyrecup and Phytophthora spp.) on marri (Corymbia calophylla) tree health in southwest Western Australia. Annals of Forest Science 74: 1-62. https://doi.org/10.1007/s13595-017-0658-6

Paap T, Burgess TI, Rolo V, Steel E, Hardy GESJ (2018) Anthropogenic disturbance impacts stand structure and susceptibility of an iconic tree species to an endemic canker pathogen. Forest Ecology and Management 425: 145-153. https://doi.org/10.1016/j.foreco.2018.05.055

Pautasso M, Schlegel M, Holdenrieder O (2015) Forest health in a changing world. Microbial Ecology 69: 826-842. https://doi.org/10.1007/s00248-014-0545-8

Pautasso M, Aas G, Queloz V, Holdenrieder O (2013) European ash (Fraxinus excelsior) dieback-A conservation biology challenge. Biological Conservation 158: 37-49. https:// doi.org/10.1016/j.biocon.2012.08.026

Peace TR (1962) Pathology of trees and shrubs with special reference to Britain. Oxford University Press, Oxford, 753 pp.

Pereyra PJ (2016) Revisiting the use of the invasive species concept: an empirical approach. Austral Ecology 41: 519-528. https://doi.org/10.1111/aec.12340

Perkins LB, Leger EA, Nowak RS (2011) Invasion triangle: an organizational framework for species invasion. Ecology and Evolution 1: 610-625. https://doi.org/10.1002/ece3.47 
Pluess T, Jarošík V, Pyšek P, Cannon R, Pergl J, Breukers A, Bacher S (2012) Which factors affect the success or failure of eradication campaigns against alien species? PLoS ONE 7(10): e48157. https://doi.org/10.1371/journal.pone.0048157

Power AG, Mitchell CE (2004) Pathogen spillover in disease epidemics. The American Naturalist 164: S79-S89. https://doi.org/10.1086/424610

Potgieter LJ, Cadotte MW (2020) The application of selected invasion frameworks to urban ecosystems. In: Wilson JR, Bacher S, Daehler CC, Groom QJ, Kumschick S, Lockwood JL, Robinson TB, Zengeya TA, Richardson DM (Eds) Frameworks used in Invasion Science. NeoBiota 62: 365-386. https://doi.org/10.3897/neobiota.62.50661

Potgieter LJ, Douwes E, Gaertner M, Measey J, Paap T, Richardson DM (2020) Biological invasions in South Africa's urban ecosystems: patterns, processes, impacts, and management. In: van Wilgen B, Measey J, Richardson D, Wilson J, Zengeya T (Eds) Biological Invasions in South Africa. Springer, Cham, 275-309. https://doi. org/10.1007/978-3-030-32394-3_11

Price PW, Westoby M, Rice B, Atsatt PR, Fritz RS, Thompson JN, Mobley K (1986) Parasite mediation in ecological interactions. Annual Review of Ecology and Systematics 17: 487505. https://doi.org/10.1146/annurev.es.17.110186.002415

Pyšek P, Richardson DM, Pergl J, Jarošík V, Sixtová Z, Weber E (2008) Geographical and taxonomical biases in invasion ecology. Trends in Ecology \& Evolution 23: 237-244. https://doi.org/10.1016/j.tree.2008.02.002

Pyšek P, Hulme PE, Simberloff D, Bacher S, Blackburn TM, Carlton JT, Dawson W, Essl F, Foxcroft LC, Genovesi P, Jeschke JM, Kühn I, Liebhold AM, Mandrak NE, Meyerson LA, Pauchard A, Pergl J, Roy HE, Seebens H, van Kluenen M, Vilà M, Wingfield MJ, Richardson DM (2020) Scientists' warning on invasive alien species. Biological Reviews: 1-25. https://doi.org/10.1111/brv.12627

Queloz V, Grünig CR, Berndt R, Kowalski T, Sieber TN, Holdenrieder O (2011) Cryptic speciation in Hymenoscyphus albidus. Forest Pathology 41: 133-142. https://doi. org/10.1111/j.1439-0329.2010.00645.x

Ramírez-Gil JG, Castañeda-Sánchez DA, Morales-Osorio JG (2017) Production of avocado trees infected with Phytophthora cinnamomi under different management regimes. Plant Pathology 66: 623-632. https://doi.org/10.1111/ppa.12620

Ramsfield TD, Bentz BJ, Faccoli M, Jactel H, Brockerhoff EG (2016) Forest health in a changing world: effects of globalization and climate change on forest insect and pathogen impacts. Forestry 89: 245-252. https://doi.org/10.1093/forestry/cpw018

Reed EM, Serr ME, Maurer AS, Reiskind MB (2020) Gridlock and beltways: the genetic context of urban invasions. Oecologia 13: 1-4. https://doi.org/10.1007/s00442-02004614-y

Reichard SH, White PS (2003) Invasion biology: an emerging field of study. Annals of the Missouri Botanical Garden 90: 64-66. https://doi.org/10.2307/3298526

Ricciardi A, Blackburn TM, Carlton JT, Dick JT, Hulme PE, Iacarella JC, Jeschke JM, Liebhold AM, Lockwood JL, MacIsaac HJ, Pyšek P, Richardson DM, Ruiz GM, Simberloff D, Sutherland WJ, Wardle DA, Aldridge DC (2017) Invasion science: a horizon scan of 
emerging challenges and opportunities. Trends in Ecology \& Evolution 32: 464-474. https://doi.org/10.1016/j.tree.2017.03.007

Richardson DM, Pyšek P, Rejmánek M, Barbour MG, Panetta FD, West CJ (2000) Naturalization and invasion of alien plants: concepts and definitions. Diversity and Distributions 6: 93-107. https://doi.org/10.1046/j.1472-4642.2000.00083.x

Ridley GS, Bain J, Bulman LS, Dick MA, Kay MK (2000) Science for Conservation 142: 1-68. http://www.doc.govt.nz/globalassets/documents/science-and-technical/sfc142.pdf

Rigling D, Prospero S (2018) Cryphonectria parasitica, the causal agent of chestnut blight: invasion history, population biology and disease control. Molecular Plant Pathology 19: 7-20. https://doi.org/10.1111/mpp.12542

Rizzo DM, Garbelotto M (2003) Sudden oak death: endangering California and Oregon forest ecosystems. Frontiers in Ecology and the Environment 1: 197-204. https://doi. org/10.1890/1540-9295(2003)001[0197:SODECA]2.0.CO;2

Rodoni BC, Merriman PR, McKirdy SJ, Wittwer G (2006) Costs associated with fire blight incursion management and predicted costs of future. Acta Horticulturae 704: 55-62. https://doi.org/10.17660/ActaHortic.2006.704.5

Roux J, Greyling I, Coutinho TA, Verleur M, Wingfeld MJ (2013) The myrtle rust pathogen, Puccinia psidii, discovered in Africa. IMA Fungus 4: 155-159. https://doi.org/10.5598/ imafungus.2013.04.01.14

Roy HE, Hesketh H, Purse BV, Eilenberg J, Santini A, Scalera R, Stentiford GD, Adriaens T, Bacela-Spychalska K, Bass D, Beckmann KM, Bessell P, Bojko J, Booy O, Cardoso AC, Essl F, Groom Q, Harrower C, Kleespies R, Martinou AF, van Oers MM, Peeler EJ, Pergl J, Rabitsch W, Roques A, Schaffner F, Schindler S, Schmidt BR, Schönrogge K, Smith J, Solarz W, Stewart A, Stroo A, Tricarico E, Turvey KM, Vannini A, Vilà M, Woodward S, Wynns AA, Dunn AM (2017) Alien pathogens on the horizon: opportunities for predicting their threat to wildlife. Conservation Letters 10: 477-484. https://doi.org/10.1111/conl.12297

Sakalidis ML, Slippers B, Wingfield BD, Hardy GS, Burgess TI (2013) The challenge of understanding the origin, pathways and extent of fungal invasions: global populations of the Neofusicoccum parvum-N. ribis species complex. Diversity and Distributions 19: 873883. https://doi.org/10.1111/ddi.12030

Santini A, Liebhold A, Migliorini D, Woodward S (2018) Tracing the role of human civilization in the globalization of plant pathogens. The ISME Journal 12: 647-652. https://doi. org/10.1038/s41396-017-0013-9

Santini A, Ghelardini L, De Pace C, Desprez-Loustau ML, Capretti P, Chandelier A, Cech T, Chira D, Diamandis S, Gaitniekis T, Hantula J, Holdenrieder O, Jankovsky L, Jung T, Jurc D, Kirisits T, Kunca A, Lygis V, Malecka M, Marcais B, Schmitz S, Schumacher J, Solheim H, Solla A, Szabò I, Tsopelas P, Vannini A, Vettraino AM, Webber J, Woodward S, Stenlid J (2013) Biogeographical patterns and determinants of invasion by forest pathogens in Europe. New Phytologist 197: 238-250. https://doi.org/10.1111/j.1469-8137.2012.04364.x

Scott P, Bader M, Burgess TI, Hardy GESJ, Williams N (2019) Global biogeography and invasion risk of the plant destroyer genus Phytophthora. Environmental Science and Policy 101: 175-182. https://doi.org/10.1016/j.envsci.2019.08.020 
Seebens H, Blackburn TM, Dyer EE, Genovesi P, Hulme PE, Jeschke JM, Pagad S, Pyšek P, Winter M, Arianoutsou M, Bacher S, Blasius B, Brundu G, Capinha C, Celesti-Grapow L, Dawson W, Dullinger S, Fuentes N, Jäger H, Kartesz J, Kenis M, Kreft H, Kühn I, Lenzner B, Liebhold A, Mosena A, Moser D, Nishino M, Pearman D, Perg J, Rabitsch W, RojasSandoval J, Roques A, Rorke S, Rossinelli S, Roy HE, Scalera R, Schindler S, Štajerová K, Tokarska-Guzik B, van Kleunen M, Walker K, Weigelt P, Yamanaka T, Essl F (2017) No saturation in the accumulation of alien species worldwide. Nature Communications 8: 14435. https://doi.org/10.1038/ncomms14435

Seebens H, Blackburn TM, Dyer EE, Genovesi P, Hulme PE, Jeschke JM, Pagad S, Pyšek P, van Kleunen M, Winter M, Ansong M, Arianoutsou M, Bacher S, Blasius B, Brockerhoff EG, Brundu G, Capinha C, Causton CE, Celesti-Grapow L, Dawson W, Dullinger S, Economo EP, Fuentes N, Guénard B, Jäger H, Kartesz J, Kenis M, Kühn I, Lenzner B, Liebhold AM, Mosena A, Moser D, Nentwig W, Nishino M, Pearman D, Pergl J, Rabitsch W, Rojas-Sandoval J, Roques A, Rorke S, Rossinelli S, Roy HE, Scalera R, Schindler S, Štajerová K, Tokarska-Guzik B, Walker K, Ward DF, Yamanaka T, Essl F (2018) Global rise in emerging alien species results from increased accessibility of new source pools. Proceedings of the National Academy of Sciences 115: E2264-E2273. https://doi. org/10.1073/pnas.1719429115

Shearer BL, Crane CE, Barrett S, Cochrane A (2007) Phytophthora cinnamomi invasion, a major threatening process to conservation of flora diversity in the South-west Botanical Province of Western Australia. Australian Journal of Botany 55: 225-238. https://doi. org/10.1071/BT06019

Shigo AL (1967) Successions of organisms in discoloration and decay of wood. In: Romberger JA, Mikola P (Eds) International Review of Forestry Research (Vol. 2). Elsevier, New York, 237-299. https://doi.org/10.1016/B978-1-4831-9976-4.50012-1

Slippers B, Stenlid J, Wingfield MJ (2005) Emerging pathogens: fungal host jumps following anthropogenic introduction. Trends in Ecology \& Evolution 20: 420-421. https://doi. org/10.1016/j.tree.2005.05.002

Soubeyrand S, de Jerphanion P, Martin O, Saussac M, Manceau C, Hendrikx P, Lannou C (2018) Inferring pathogen dynamics from temporal count data: the emergence of Xylella fastidiosa in France is probably not recent. New Phytologist 219: 824-836. https://doi. org/10.1111/nph.15177

Stenlid J, Oliva J (2016) Phenotypic interactions between tree hosts and invasive forest pathogens in the light of globalization and climate change. Philosophical Transactions of the Royal Society B: Biological Science 371: 20150455. https://doi.org/10.1098/rstb.2015.0455

Swart, WJ, Wingfield MJ (1991) Biology and control of Sphaeropsis sapinea on Pinus species in South Africa. Plant Disease 75: 761-766. https://doi.org/10.1094/PD-75-0761

Tainter FH, Baker FA (1996) Principles of forest pathology. John Wiley \& Sons, New York, $805 \mathrm{pp}$.

Taylor JW, Jacobson DJ, Kroken S, Kasuga T, Geiser DM, Hibbett DS, Fisher MC (2000) Phylogenetic species recognition and species concepts in fungi. Fungal Genetics and Biology 31: 21-32. https://doi.org/10.1006/fgbi.2000.1228

Tedersoo L, Bahram M, Pólme S, Yorou NS, Wijesundera R, Villarreal Ruiz L, Vasco-Palacios AM, Thu PQ, Suija A, Smith ME, Sharp C, Saluveer E, Saitta A, Rosas M, Riit T, Ratkowsky 
D, Pritsch K, Póldmaa K, Piepenbring M, Phosri C, Peterson M, Parts K, Pärtel K, Otsing E, Nouhra E, Njouonkou AL, Nilsson RH, Morgado LN, Mayor J, May TW, Majuakim L, Lodge DJ, Lee SS, Larsson KH, Kohout P, Hosaka K, Hiiesalu I, Henkel TW, Harend H, Guo LD, Greslebin A, Grelet G, Geml J, Gates G, Dunstan W, Dunk C, Drenkhan R, Dearnaley J, De Kesel A, Dang T, Chen X, Buegger F, Brearley FQ, Bonito G, Anslan S, Abell S, Abarenkov K (2014) Global diversity and geography of soil fungi. Science 346: 1256688. https://doi.org/10.1126/science.1256688

Thakur MP, van der Putten WH, Cobben MMP, van Kleunen M, Geisen S (2019) Microbial invasions in terrestrial ecosystems. Nature Reviews Microbiology 17: 621-631. https://doi. org/10.1038/s41579-019-0236-z

Thompson LR, Sanders JG, McDonald D, Amir A, Ladau J, Locey KJ, Prill RJ, Tripathi A, Gibbons SM, Ackermann G, Navas-Molina JA, Janssen S, Kopylova E, Vázquez-Baeza Y, González A, Morton JT, Mirarab S, Zech Xu Z, Jiang L, Haroon MF, Kanbar J, Zhu Q, Jin Song S, Kosciolek T, Bokulich NA, Lefler J, Brislawn CJ, Humphrey G, Owens SM, Hampton-Marcell J, Berg-Lyons D, McKenzie V, Fierer N, Fuhrman JA, Clauset A, Stevens RL, Shade A, Pollard KS, Goodwin KD, Jansson JK, Gilbert JA, Knight R (2017) Earth Microbiome Project Consortium. A communal catalogue reveals Earth's multiscale microbial diversity. Nature 551: 457-463. https://doi.org/10.1038/nature24621

Thomsen MS, Olden JD, Wernberg T, Griffin JN, Silliman BR (2011) A broad framework to organize and compare ecological invasion impacts. Environmental Research 111: 899908. https://doi.org/10.1016/j.envres.2011.05.024

Traveset A, Richardson DM (in press) Plant invasions: the role of biotic interactionsan overview. In: Traveset A, Richardson DM (Eds) Plant Invasions: the Role of Biotic Interactions. CABI, Wallingford, $25 \mathrm{pp}$.

Trumbore S, Brando P, Hartmann H (2015) Forest health and global change. Science 349: 814-818. https://doi.org/10.1126/science.aac6759

Vainio EJ, Bezos D, Bragança H, Cleary M, Fourie G, Georgieva M, Ghelardini L, Hannunen S, Ioos R, Martín-García J, Martínez-Álvarez P, Mullett M, Oszako T, Papazova-Anakieva I, Piškur B, Romeralo C, Sanz-Ros AV, Steenkamp ET, Tubby K, Wingfield MJ, Diez JJ (2019) Sampling and detection strategies for the pine pitch canker (PPC) disease pathogen Fusarium circinatum in Europe. Forests 10: 1-723. https://doi.org/10.3390/f10090723

Werres S, Marwitz R, Man in't Veld WA, Cock AWAMde, Bonants PJM, Weerdt Mde, Themann K, Ilieva E, Baayen RP (2001) Phytophthora ramorum sp. nov., a new pathogen on Rhododendron and Viburnum. Mycological Research 105: 1155-1165. https://doi. org/10.1016/S0953-7562(08)61986-3

Weste GM, Taylor P (1971) The invasion of native forest by Phytophthora cinnamomi. I. Brisbane Ranges, Victoria. Australian Journal of Botany 19: 281-294. https://doi.org/10.1071/ BT9710281

Williamson M (1996) Biological Invasions. Chapman and Hall, London, 244 pp.

Wilson JRU, Bacher S, Daehler CC, Groom QJ, Kumschick S, Lockwood JL, Robinson TB, Zengeya TA, Richardson DM (2020) Frameworks used in invasion science: progress and prospects. In: Wilson JR, Bacher S, Daehler CC, Groom QJ, Kumschick S, Lockwood JL, Robinson TB, Zengeya TA, Richardson DM (Eds) Frameworks used in Invasion Science. NeoBiota 62: 1-30. https://doi.org/10.3897/neobiota.62.58738 
Wilson JR, Foxcroft LC, Geerts S, Hoffman MT, MacFadyen S, Measey J, Mills A, Richardson DM, Robertson MP, van Wilgen BW (2020) The role of environmental factors in promoting and limiting biological invasions in South Africa. In: van Wilgen B, Measey J, Richardson D, Wilson J, Zengeya T (Eds) Biological Invasions in South Africa. Springer, Cham, 355-385. https://doi.org/10.1007/978-3-030-32394-3_13

Wilson JRU, Datta A, Hirsch H, Keet J-H, Mbobo T, Nkuna KV, Nsikani MM, Pyšek P, Richardson DM, Zengeya TA, Kumschick S (2020) Is invasion science moving towards agreed standards? The influence of selected frameworks. In: Wilson JR, Bacher S, Daehler CC, Groom QJ, Kumschick S, Lockwood JL, Robinson TB, Zengeya TA, Richardson DM (Eds) Frameworks used in Invasion Science. NeoBiota 62: 569-589. https://doi. org/10.3897/neobiota.62.53243

Wingfield MJ, Brockerhoff EG, Wingfield BD, Slippers B (2015) Planted forest health: the need for a global strategy. Science 349: 832-836. https://doi.org/10.1126/science.aac6674

Wingfield MJ, Slippers B, Wingfield BD, Barnes I (2017) The unified framework for biological invasions: a forest fungal pathogen perspective. Biological Invasions 19: 3201-3214. https://doi.org/10.1007/s10530-017-1450-0

Wingfield MJ, Hammerbacher A, Ganley RJ, Steenkamp ET, Gordon TR, Wingfield BD, Coutinho TA (2008) Pitch canker caused by Fusarium circinatum-a growing threat to pine plantations and forests worldwide. Australasian Plant Pathology 37: 319-334. https://doi. org/10.1071/AP08036

Xie T, Liu W, Anderson BD, Liu X, Gray GC (2017) A system dynamics approach to understanding the One Health concept. PloS ONE 12(9): e0184430. https://doi. org/10.1371/journal.pone.0184430

Zinger L, Bonin A, Alsos IG, Bálint M, Bik H, Boyer F, Chariton AA, Creer S, Coissac E, Deagle BE, De Barba M, Dickie IA, Dumbrell AJ, Ficetola GF, Fierer N, Fumagalli L, Gilbert MTP, Jarman S, Jumpponen A, Kauserud H, Orlando L, Pansu J, Pawlowski J, Tedersoo L, Thomsen PF, Willerslev E, Taberlet P (2019) DNA metabarcoding - need for robust experimental designs to draw sound ecological conclusions. Molecular Ecology 28: 1857-1862. https://doi.org/10.1111/mec.15060 